\title{
Foliar application of molybdenum on cover crops and response of common beans in successive cultivation ${ }^{l}$
}

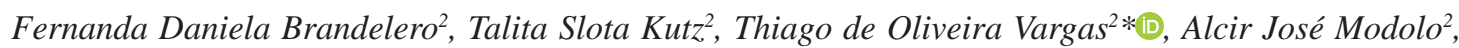 \\ Luís César Cassol², Marisa de Cacia Oliveira ${ }^{3}$, Ricardo Henrique Silva Santos ${ }^{4}$
}

10.1590/0034-737X202067010006

\begin{abstract}
The effects of foliar application of Mo and use of $\mathrm{N}$ from cover crops (Crotalaria juncea $\mathrm{L}$. and Canavalia ensiformis (L.) DC) on the performance of common beans were investigated in this study. Field experiments were carried out in a succession planting system (cover crops - common beans), and nitrate reductase activities were evaluated in the laboratory. For the production of cover crops, a $2 \times 4$ factorial scheme was installed, with the two cover crops sunn hemp and jack bean, along with four doses of $\mathrm{Mo}\left(0,40,80\right.$, and $\left.120 \mathrm{~g} \mathrm{ha}^{-1}\right)$ in the form of sodium molybdate $\left(\mathrm{Na}_{2} \mathrm{MoO}_{4}\right)$ through foliar application in random blocks with four replications. For bean cultivation, an unfertilized control treatment was evaluated. Sunn hemp showed a linear positive response to Mo application in terms of shoot dry matter and $\mathrm{N}$ accumulation, while jack bean showed a quadratic negative response for shoot dry matter; for $\mathrm{N}$ accumulation, there was no adjustment of the regression models. Nitrate reductase activity in the common beans was up to three times higher at the Mo dose of $0 \mathrm{~g} \mathrm{ha}^{-1}$ when compared to the treatments with Mo application to both cover crops. Cover crops or Mo doses had no significant effect on bean productivity.
\end{abstract}

Keywords: legumes; nitrogen; enzyme activity; nitrate reductase.

\section{INTRODUCTION}

Despite the potential benefits, the use of legumes in cover crops production is still not a common practice in production systems. Generally, commercial crops occupy most of the agriculturally used area, with potential negative consequences for soil quality. Studies demonstrating the efficiency of the use of legumes, especially in succession planting, serve as stimulus to the expansion of the adoption of this practice by farmers.

Studies on the increase in nitrogen metabolism, generated through the application of molybdenum (Mo) in leguminous crops used for fertilization, can contribute to a better scientific understanding of the processes involved in cover crop application. A recent study has shown that the application of Mo in common beans via seeds raises the mass of nodules formed by native rhizobia
(Matoso \& Kusdra, 2014), whereas foliar application increases the formation of nodules, the foliar nitrogen content, the number of grains per pod, the mass of 100 grains, and overall productivity (Albuquerque et al., 2012).

These benefits may be associated with the processes of absorption and assimilation of $\mathrm{N}$ in the soil, fixed via $\mathrm{BNF}$ (biological nitrogen fixation), since molybdenum (Mo) plays an important role in the regulation of reductase and nitrogenase synthesis, durability, and continuity (Almeida et al., 2013). Thus, plants receiving Mo applications show increased $\mathrm{N}$ levels a productivity, based on the higher activities of these enzymes (Almeida et al., 2013; Lopes et al., 2014; Matoso \& Kusdra, 2014).

However, there are few studies concerning the application of Mo in leguminous crops used as cover crops. Knowledge about the effects of the application of

\footnotetext{
Submitted on March 07 th, 2019 and accepted on November 18 th, 2019.

${ }^{1}$ This work is part of the first author Master's thesis.

${ }^{2}$ Universidade Tecnológica Federal do Paraná, Programa de Pós-Graduação em Agronomia, Pato Branco, Paraná, Brazil. fernanda.brandelero@gmail.com; talitaslota@hotmail.com; thiagovargas@utfpr.edu.br; alcir@utfpr.edu.br; cassol@utfpr.edu.br

${ }^{3}$ Universidade Tecnológica Federal do Paraná, Departamento de Ciências Agrárias, Pato Branco, Paraná, Brazil. mcacia@utfpr.edu.br

${ }^{4}$ Universidade Federal de Viçosa, Programa de Pós-Graduação em Fitotecnia, Viçosa, Minas Gerais, Brazil. rsantos@ufv.br

*Corresponding author: thiagovargas@utfpr.edu.br
} 
this micronutrient in cover crops and the transfer of $\mathrm{N}$ in succession planting significantly contributes to our understanding of the processes associated with a new management strategy for cover crops plants, aiming at a greater availability of nutrients for crops of commercial interest.

In this context, we evaluated effect of Mo application and $\mathrm{N}$ from cover crops Crotalaria juncea and Canavalia ensiformis in terms of common beans performance in succession planting.

\section{MATERIAL AND METHODS}

The experiment took place from October 22, 2014 to June 25, 2015, in the experimental area of the Universidade Tecnológica Federal do Paraná, Pato Branco campus (26 06' $593 \mathrm{~S}$ and 52 40' 59"W, $760 \mathrm{~m}$ above sea level). The soil is classified as Typic Hapludox (Soil Survey Staff, 2014), with the following chemical characteristics of the top soil $(0-20 \mathrm{~cm})$ layer: $\mathrm{pH}$ in $\mathrm{CaCl}_{2}=5.1 ; \mathrm{P}($ Mehlich-1 $)=$ $3.28 \mathrm{mg} \mathrm{dm}^{-3} ; \mathrm{K}, \mathrm{Ca}, \mathrm{Mg}, \mathrm{H}+\mathrm{Al}, \mathrm{SB}, \mathrm{CTC}=0.18,5.40,2.10$, $4.61,7.68,12.29 \mathrm{cmol} \mathrm{dm}^{-3}$, respectively; $\mathrm{V}=62.49 \%$, and $\mathrm{MO}=37.53 \mathrm{~g} \mathrm{dm}^{-3}$. The region has a mesothermic humid subtropical climate; precipitation and temperature data for the experimental period are shown in Figure 1.

Cover crops cultivation was conducted in a $2 \times 4$ factorial scheme, using sunn hemp (Crotalaria juncea) and jack bean (Canavalia ensiformis), along with four Mo doses $\left(0,40,80\right.$, and $\left.120 \mathrm{~g} \mathrm{ha}^{-1}\right)$ in the form of sodium molybdate $\left(\mathrm{Na}_{2} \mathrm{MoO}_{4}\right)$ through foliar application in random blocks with four replications, totaling 32 experimental units (EU). Each plot corresponded to an area of $2.25 \mathrm{~m}$ in width $\mathrm{x} 5.0 \mathrm{~m}$ in length, totaling $11.25 \mathrm{~m}^{2}$.

The cover crops were sown on 22 October 2014. The sowing line groove was opened with a no-tillage seeder, with $0.45 \mathrm{~m}$ spacing between lines, and the seeds were distributed manually, without base fertilization. Six jack bean crops and 22 sunn hemp plants were planted per linear meter.

When jack bean reached the stage V4, Mo was applied to both cover crops. This developmental phase was chosen because of the positive results of previous works with Mo application in common beans (Pires et al., 2005; Albuquerque et al., 2012; Lopes et al., 2014). For Mo application, we used a manual sprayer with a flat fan nozzle, and an adjuvant was used to spray $2 \mathrm{~L}$ per plot.

At 105 DAS (days after sowing), cover crop samples were collected for quantification of shoot dry matter (DM) and $\mathrm{N}$ accumulation. The remaining plants in the plot were harvested using a manual brush cutter and deposited in one piece inside the experimental boundaries established.

The sampling of plant material for DM and $\mathrm{N}$ quantification was performed with the help of a metal frame $\left(0.25 \mathrm{~m}^{2}\right)$, which was randomly placed in two separate locations within each plot. The species were cut close to the ground, weighed, and oven-dried at $60^{\circ} \mathrm{C}$ until reaching a constant mass. After drying, the samples were ground in a Willey-type mill for determination of the total $\mathrm{N}$ concentration, using the Kjeldahl method (Tedesco et al., 1995).

Four days after cover crop harvesting, on February 9, 2015, the common beans cultivar IPR 'Tuiuiú' was sown. The cultivar belongs to the group of black beans, has indeterminate type II growth response, and is erect, with an 88-day average cycle and a yield potential of around $3,950 \mathrm{~kg} \mathrm{ha}^{-1}$; average mass of 1,000 seeds is $227 \mathrm{~g}$.

A $(2 \times 4)+1$ factorial scheme was used in succession planting; common beans were sown in the plots under the two species of cover crop and four doses of Mo, plus one additional treatment (planned earlier, the

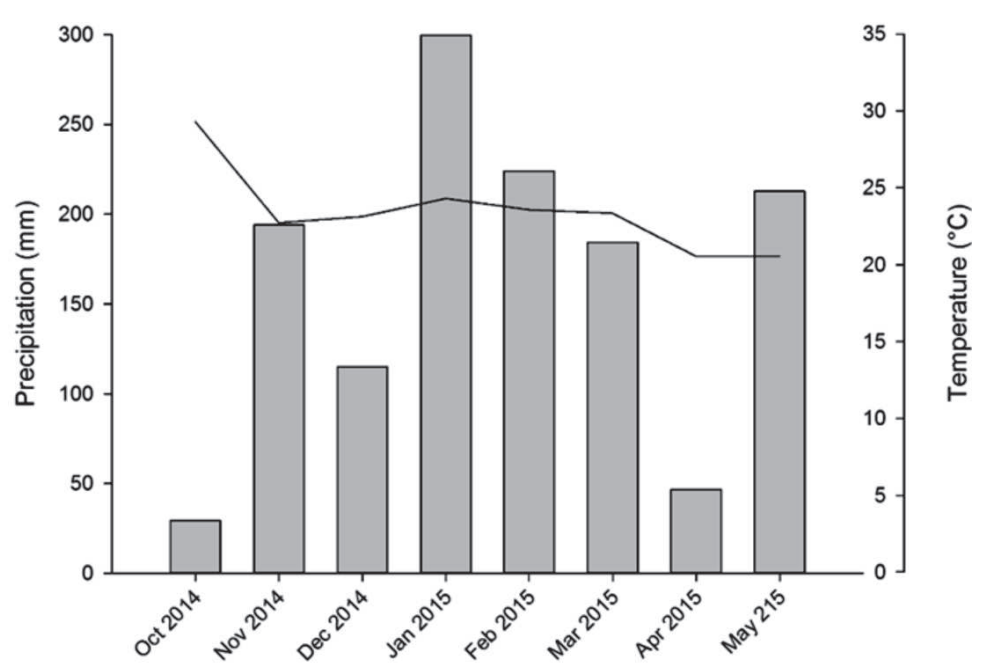

Figure 1: Precipitation $(\mathrm{mm})$ and average temperature $\left({ }^{\circ} \mathrm{C}\right)$ for the city of Pato Branco, Paraná, during the experimental period. 
corresponding plot received no Mo fertilization), in random blocks with four replications, totaling 36 experimental units (EUs). Sowing was carried out manually without soil preparation and at a spacing of $0.45 \mathrm{~m}$ between rows, with 12 seeds per linear meter. No fertilization was performed both before and after sowing, without inoculation with $\mathrm{N}$ fixing strains.

Samples for the quantification of shoot dry matter (DM) were also collected, following the same methodology as described for the cover crops. Bean grain harvesting was performed manually at the stage of physiological maturity, on 14 May 2015, at 94 DAS; threshing was performed mechanically within each parcel. Productivity was estimated for the grains harvested in the three central lines of the plot, calculated with adjustment of humidity to $13 \%$. In the central line, assessment of the yield components was performed in 10 randomly selected plants, determining the following parameters: number of pods per plant, number of grains developed per pod, number of grains developed per plant, and mass of 100 grains.

In vivo nitrate reductase activity was evaluated in cover crops and common beans at 90 and 66 DAS, respectively. For this, foliar samples were collected in the early morning from the mid-third parts of the plants and packed with ice in a Styrofoam box (Toledo et al., 2010). The tests followed the methodology proposed by Jaworski (1971), with adaptations.

The data were submitted to analysis of variance. When an interaction between Mo doses and species were observed, polynomial regression analysis was carried out; the models were selected according to the criterion of the greater $\mathrm{R}^{2}$ and the significance $(\mathrm{p}<0.05)$ of the equation's parameters. For the control evaluations, when significant differences between the treatment and control averages were observed, Dunnett's test was used to compare these differences $(\mathrm{p}<0.05)$. For all analyses, the software package ASSISTAT was used (Silva \& Azevedo, 2016).

\section{RESULTS AND DISCUSSION}

There was a significant interaction between species $\mathrm{x}$ doses of Mo for the accumulation of DM and $\mathrm{N}$ in the cover crop. For the accumulation of DM in sunn hemp (DM_sunn hemp), the $120 \mathrm{~g} \mathrm{ha}^{-1}$ dose resulted in the highest response (34.19 $\left.\mathrm{tha}^{-1}\right)$, showing linear adjustment of data, with a nearly $13,7 \%$ increase in the accumulation of DM between the doses 0 and $120 \mathrm{~g} \mathrm{ha}^{-1}$. Jack beans (DM_jack bean) showed no significance response, with an average of $12.05 \mathrm{tha}^{-1}$ of DM. For all doses studied, the accumulation of sunn hemp shoot dry matter was greater than that of jack beans (Fig. 2a).

The responses to the accumulation of $\mathrm{N}(\mathrm{N})$ were similar to those of DM. Sunn hemp showed a positive linear response to Mo doses, reaching 545,49 $\mathrm{kg} \mathrm{N} \mathrm{ha}^{-1}$ at the highest dose of Mo applied. According to the regression equation, for each $100 \mathrm{~g}$ of $\mathrm{Mo} \mathrm{ha}^{-1}$ applied, we observed an accumulation of $113 \mathrm{~kg}$ of $\mathrm{N} \mathrm{ha}^{-1}$ (Fig. 2b).

Although there is no information in the literature about the application of Mo in cover crops, its purpose is believed to be similar to those observed for other legumes associated with $\mathrm{N}$-fixing bacteria, since various studies base their positive results on the performance of Mo as a cofactor of enzyme nitrogenase and nitrate reductase, which are responsible for biological $\mathrm{N}$ fixation and assimilation, respectively (Pessoa et al., 2000; Matoso \& Kusdra, 2014; Bertoldo et al., 2015).

However, in this study, we observed differences in the accumulation of DM and $\mathrm{N}$ between sunn hemp and jack bean. This finding can be attributed to the sampling time, as the material was collected when the plants were in the phenological phase. Similar results were found by Carvalho et al. (2015), who, when assessing the DM of cover plants during the flowering and physiological maturation periods, found $2.32 \mathrm{t} \mathrm{ha}^{-1}$ of DM in sunn hemp during the flowering period and $2.42 \mathrm{t} \mathrm{ha}^{-1}$ during maturation. Similarly, for Barbicou-beans (Canavalia brasiliensis), $3.30 \mathrm{t} \mathrm{ha}^{-1}$ of DM were found during flowering and $2.75 \mathrm{t}$ $\mathrm{ha}^{-1}$ during maturation. Other factors, such as genetic differences in the absorption and use of Mo (Nie et al., 2014; Liu et al., 2017), as well as the time and form of Mo application, may also have contributed to these results.

As the two species showed distinct phenological responses, it was not possible to carry out a compatibilization of the developmental stages at harvest (105 DAS). While jack beans were in the reproductive stage, with flowering and pod formation, sunn hemp was still in the vegetative stage. Sunn hemp is responsive to the photoperiod and has been classified as a short-day plant (Santos \& Junior, 2003), and in Pato Branco, it flowers after the first two weeks of February, which was after harvesting. In this way, without flower induction, sunn hemp remained in the vegetative phase throughout the entire experimental period, with high biomass accumulation; Leal et al. (2012) have also observed similar results.

Sunn hemp responded linearly to the Mo doses and did not obtain its maximum DM and $\mathrm{N}$ accumulation levels. In contrast, jack bean, with its relatively large seeds, showed a different response, possibly due to the considerable Mo amounts in the seeds. In a study by Kubota et al. (2008) on bean seeds, the authors found that seeds with high levels of Mo can generate plants that do not respond to the additional application of this element; Almeida et al. (2013) when assessing the response of common bean seeds to Mo supplementation have found similar results. 
Regardless of the variation caused by Mo application, the results obtained in this study indicate the adaptability of these cover crop to the environmental conditions of southwestern Paraná, as the DM values were similar to those observed by Vargas et al. (2011) in Viçosa, MG, where cover crop are adapted to the local conditions, with 30.60 and $19.94 \mathrm{t} \mathrm{ha}^{-1}$ for sunn hemp and jack bean, respectively, at 118 DAS. Cavalcante et al. (2012) in São Vicente da Serra, MT, found lower DM values with $3.0 \mathrm{t}$ $\mathrm{ha}^{-1}$ for sunn hemp and jack bean.

For all Mo doses examined, the accumulation of $\mathrm{N}$ in sunn hemp was greater than in jack bean because of the high DM accumulation of sunn hemp, although its $\mathrm{N}$ content $(1.5 \%)$ is lower that that of jack bean $(2.4 \%)$, resulting in an average $\mathrm{N}$ accumulation of 477.69 and $294.27 \mathrm{~kg} \mathrm{ha}^{-1}$ for sunn hemp and jack bean, respectively. A similar linear response for sunn hemp was obtained by Pessoa et al. (2000) for common beans fertilized with Mo, which, according to the authors, is associated with increased amounts of nitrogenase (BNF) and nitrate reductase (reduction of $\mathrm{N}$ absorbed from the soil).

The performance of the common beans, in succession to the cover crop grown with different doses of molybdenum, was not affected by the treatments. However, significant differences in relation to the control were found for the following variables: number of pods per plant (sunn hemp $40 \mathrm{~g} \mathrm{ha}^{-1}$ of Mo, jack bean 40 and 80 $\mathrm{g} \mathrm{ha}^{-1}$ of Mo) and number of developed grains per plant (sunn hemp at $40-\mathrm{g} \mathrm{ha}^{-1}$ of Mo) (Table 1). It should be noted that the addition of $40 \mathrm{~g}^{\mathrm{Mo} \mathrm{ha}} \mathrm{h}^{-1}$ to sunn hemp resulted in the highest rates for both variables, with about $50 \%$ more grains and pods per plant when compared to the control.

It is important to highlight that the experimental plots were not fertilized, with the exception of the control. The overall average productivity obtained was $1,917 \mathrm{~kg} \mathrm{ha}^{-1}$, less than the maximum potential productive of the cultivar, which is $3,950 \mathrm{~kg} \mathrm{ha}^{-1}$. However, the value observed is higher than the average for Paraná in the 2014/2015 agricultural year, which was $1,756 \mathrm{~kg} \mathrm{ha}^{-1}$.

One of the factors that may have contributed to the lack of effect of the treatments on productivity is related to the patchy distribution of rainfall throughout the growing period (Fig. 1), despite the accumulation of 442 $\mathrm{mm}$ throughout the crop cycle. In April (phase of flowering and grain filling), the average monthly rainfall was only 48 $\mathrm{mm}$, which was less than the quantity recommended by Pereira et al. (2014). In Lima common beans (Phaseolus lunatus L.), Oliveira et al. (2014) noted that water deficiency during flowering and pod formation causes the fall of flowers and pods. In common beans, stress at this stage may result in a production reduction of up to $40 \%$ (Calvache et al., 1997).

In the evaluation of nitrate reductase (NR) in cover crops, we observed a significant interaction between

Table 1: Number of pods (NP) and number of grains (NG) developed over two cover crops with different doses of molybdenum in comparison with the control

\begin{tabular}{lcl}
\hline Treatments & NP & NG \\
\hline Control & 7.62 & 44.62 \\
Bean_Sunn hemp 0 & 9.87 & 65.37 \\
Bean_Sunn hemp 40 & $15.62^{*}$ & $86.37^{*}$ \\
Bean_Sunn hemp 80 & 11.50 & 63.62 \\
Bean_Sunn hemp 120 & 10.00 & 58.50 \\
Bean_Jack bean 0 & 9.25 & 49.25 \\
Bean_Jack bean 40 & $13.00^{*}$ & 63.75 \\
Bean_Jack bean 80 & $13.00^{*}$ & 70.50 \\
Bean_Jack bean 120 & 11.25 & 58.00 \\
\hline CV(\%) & 17.79 & 20.99 \\
\hline
\end{tabular}

Means followed by * within one column differ from the control at $5 \%$ probability of error by the Dunnett test.
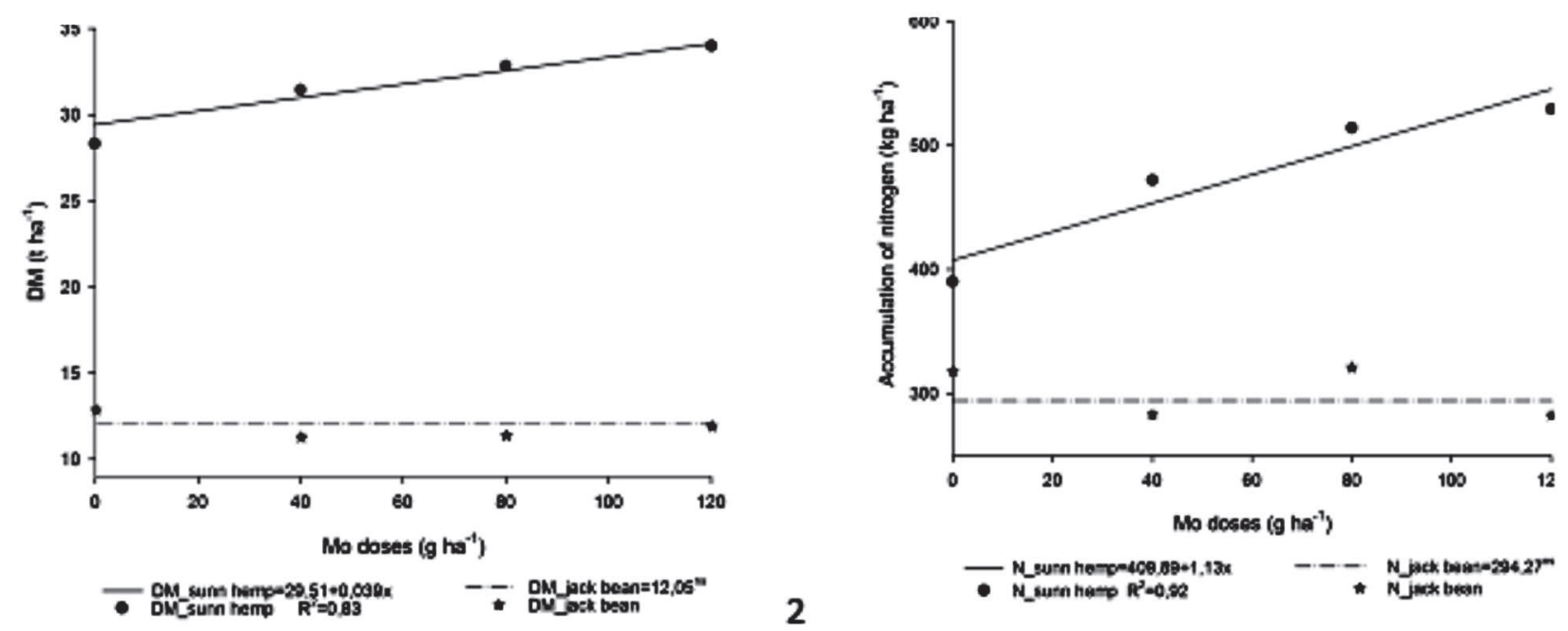

Figure 2: a) Accumulation of shoot dry matter $\left(\mathrm{t} \mathrm{ha}^{-1}\right)$ and b) nitrogen $\left(\mathrm{kg} \mathrm{ha}^{-1}\right)$ in cover crop under different molybdenum doses.

Rev. Ceres, Viçosa, v. 67, n.1, p. 035-041, jan/feb, 2020 
species and Mo doses. Both species showed a quadratic response in relation to the Mo doses applied. There was a negative effect for jack beans, with a higher activity at $120 \mathrm{~g} \mathrm{Mo} \mathrm{ha}^{-1}$, whereas sunn hemp exhibited a positive effect, with a maximum of $1.34 \mathrm{mmol} \mathrm{NO} \mathrm{N}^{2-} \mathrm{h}^{-1} \mathrm{~g}^{-1} \mathrm{MC}$ (moisture content) at a Mo dose of $71.18 \mathrm{~g} \mathrm{ha}^{-1}$ (Fig. 3a).

The activity of an enzyme is governed by several biological factors, which are associated with external stimuli. The development stage is one of these factors, influencing the decrease in NR activity during the plant's reproductive phase (Pessoa et al., 2000). The synthesis of NR is also rapidly induced in the presence of substrate, in this case, nitrate (Almeida et al., 2013), except when the availability of Mo is limited (Bredemeier \& Mudstock, 2000), which possibly occurred at the dose of $0 \mathrm{~g} \mathrm{ha}^{-1}$.

When Mo and substrate are available, enzyme synthesis is induced. The increase in Mo availability through foliar applications of linear doses of Mo may lead to increased absorption and synthesis of nitrate (Pessoa et al., 2000; Matoso \& Kusdra, 2014), favoring enzymatic activity as well as DM and $\mathrm{N}$ accumulation. However, the accumulation of $\mathrm{N}$ was higher at the highest dose of Mo applied $\left(120 \mathrm{~g} \mathrm{ha}^{-1}\right)$, although enzymatic activity showed a greater response to the dose of $40 \mathrm{~g} \mathrm{ha}^{-1}$. We therefore assume that the biological $\mathrm{N}$ fixation also increased with increasing Mo doses, with a greater contribution of atmospheric N, as noted by Pessoa et al. (2000).

When we analyzed the effect of the different Mo doses, we observed a significant interaction between species and doses, with a quadratic negative response for common beans grown under both cover crop (Fig. 3b). The induction of nitrate reductase synthesis can significantly be affected by water deficit (Marur et al., 2000), triggered by the decline of nitrate flow due to a lack of soil moisture. However, the observed values were within the ranges

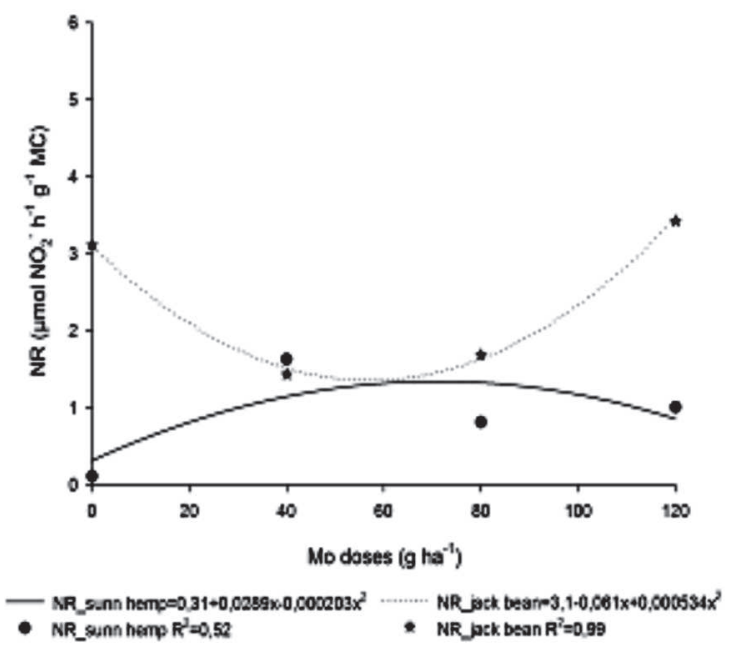

obtained by Almeida et al. (2013) for beans, with activities between 0.3 and 1.7 ìmol $\mathrm{NO}_{2}{ }^{-} \mathrm{h}^{-1} \mathrm{~g}^{-1} \mathrm{MC}$.

At the time of plant material collection, the common beans were between the developmental stages R7 and R8 (between the early formation of pods and the filling of the first pods). This period, according to a survey carried out by Bredemeier \& Musdtock (2000), represents the longest period in which the crops require $\mathrm{N}$, and in the grainfilling phase, the decreased nitrate absorption and assimilation and nodule senescence begin. The plants then start to remobilize the $\mathrm{N}$ present in its tissues to fill the grains. However, the presence of Mo prolongs the activity of both enzymes (Almeida et al., 2013).

For a same dose of Mo, NR activity in the common beans was higher when the plants were grown after jack bean cultivation (Fig. 3b), probably as a result of the more accelerated $\mathrm{N}$ mineralization in jack beans.

In the evaluation of the activity of NR in the common beans, only three treatments differed significantly from the control without cover crop or Mo application: residues of sunn hemp and jack beans without Mo, and the latter with $120 \mathrm{~g} \mathrm{ha}^{-1}$ of Mo (Table 2).

Nitrate deficiency leads to low enzyme synthesis and, consequently, low activity. This was also found for the control, which did not receive any fertilization and, consequently, had low nitrate levels. However, in the presence of cover crop, decomposition processes occur, along with $\mathrm{N}$ mineralization. This results in significant amounts of available nitrate, facilitating NR synthesis and activity (Pessoa et al., 2001; Almeida et al., 2013), which was also observed in our study.

In other treatments, even in the presence of substrate, NR levels were similar to those of the control. Almeida $e t$ al. (2013) and Pessoa et al. (2001) have observed the same response in later developmental stages of plants that

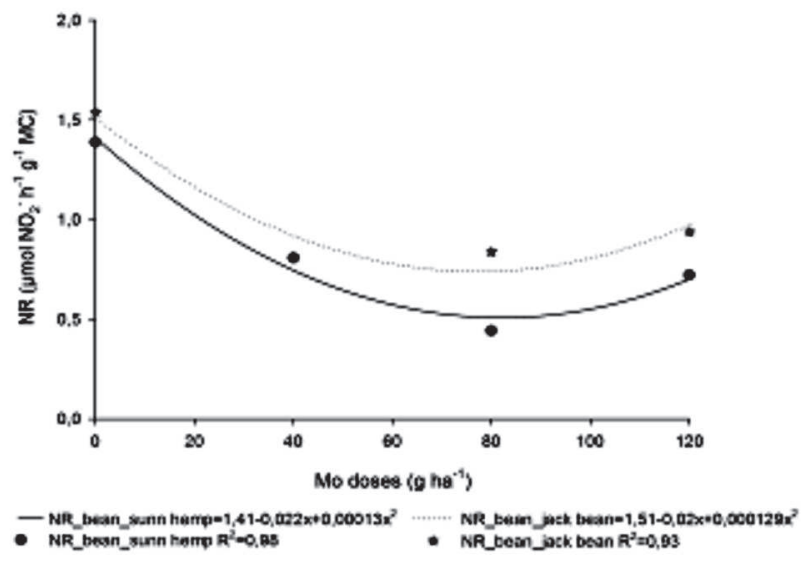

Figure 3: a) Nitrate reductase (NR) activity in cover crop species under different doses of molybdenum 90 days after sowing and b) nitrate reductase (NR) activity in common beans 66 days after sowing, grown after the cultivation of two cover crop grown with different molybdenum doses. 
Table 2: Nitrate reductase (NR) activity in the common beans 66 days after sowing after the cultivation of two cover crop grown with different molybdenum doses.

\begin{tabular}{lc}
\hline Treatments & NR $\left(\mathbf{m m o l} \mathbf{~ N O}^{2-} \mathbf{h}^{-1} \mathbf{g}^{-1} \mathbf{d e ~ M C}\right)$ \\
\hline Control & 0.52 \\
Bean_Sunn hemp 0 & $1.39 *$ \\
Bean_Sunn hemp 40 & 0.81 \\
Bean_Sunn hemp 80 & 0.44 \\
Bean_Sunn hemp 120 & 0.72 \\
Bean_Jack bean 0 & $1.54 *$ \\
Bean_Jack bean 40 & 0.81 \\
Bean_Jack bean 80 & 0.84 \\
Bean_Jack bean 120 & $0.94 *$ \\
\hline CV(\%) & 16.50
\end{tabular}

Means followed by * within one column differ from the control at $5 \%$ probability of error by the Dunnett test.

received Mo fertilization, due to the maintenance of nitrogenase activity rates.

The activity of nitrate reductase, by itself, does not provide all the explanation necessary for the discussion of the effect of Mo applied to cover crop. However, it can be used to infer about the use of the nitrate made available from the decomposition of plant residue by common beans.

It is not possible to say whether the residual Mo would be sufficient to increase the NR activity; however, the results obtained for common beans indicate that of the addition of cover crop resulted in a higher enzymatic activity compared to the control. Common beans, as well as the cover crop, can form a symbiotic association with $\mathrm{N}$-fixing bacteria; thus, it is possible that part of the nutrients also contributed to nitrogenase activity.

In this way, nitrogenase, responsible for BNF, can explain, in conjunction with nitrate reductase, the processes involved in the assimilation and metabolism of $\mathrm{N}$.

\section{CONCLUSIONS}

The foliar application of Mo resulted in an increased accumulation of shoot dry matter and $\mathrm{N}$ in the cultivation of sunn hemp, while this effect was not observed for jack bean.

Common beans productivity was not affected by Mo doses and previous cultivation of cover crops.

Nitrate reductase activity was influenced by the developmental stage of the legume species and by the Mo doses applied.

\section{ACKNOWLEDGEMENTS, FINNANCIAL SUPPORT AND FULL DISCLOSURE}

We thank "Conselho Nacional de Desenvolvimento Científico e Tecnológico (CNPq)", "Coordenação de Aper- feiçoamento de Pessoal de Nível Superior (CAPES)" and

"Fundação Araucária" for financial support.

\section{CONFLICTS OF INTERESTS}

The authors declare that there is no conflict of interests.

\section{REFERENCES}

Albuquerque HC, Pegoraro RF, Vieira NMB, Amorim IJF \& Kondo MK (2012) Nodulor capability and agronomic characteristics of common bean plants subjected to fragmented molybdenum and nitrogen fertilization. Revista Ciência Agronômica, 43:214221 .

Almeida FFD, Araújo AP \& Alves BJR (2013) Seeds with high molybdenum concentration improved growth and nitrogen acquisition of rhizobium-inoculated and nitrogen-fertilized common bean plants. Revista Brasileira de Ciência do Solo, $37: 367-378$.

Bertoldo JG, Pelisser A, Silva RPD, Favreto R \& Oliveira LADD (2015) Alternatives in bean fertilization to reduce the application of N-urea. Pesquisa Agropecuária Tropical, 45:348-355.

Bredemeier C \& Mundstock CM (2000) Regulation of nitrogen absortion and assimilation in plants. Ciência Rural, 30:365-372.

Calvache AM, Reichardt K, Malavolta E \& Bacchi OOS (1997) Effect of water deficit and of nitrogen fertilization on yield and water use efficiency in a common bean crop. Scientia Agricola, 54:232-240.

Carvalho AM, Coser TR, Rein TA, Araujo Dantas R, Silva RR \& Souza KW (2015) Management of cover crops at flowering and physiological maturity and its effect on maize yield. Pesquisa Agropecuária Brasileira, 50:551-561.

Cavalcante VS, Santos VR, Neto S, Santos MA, Santos CGD \& Costa LC (2012) Biomass production and nutrient removal by plant cover. Revista Brasileira de Engenharia Agrícola e Ambiental, 16:521-528.

Jaworski EG (1971) Nitrate reductase assay in intact plant tissues. Biochemical and Biophysical Research Communications, 43:1274-1279.

Kubota FY, Andrade Neto AC, Araújo AP \& Teixeira MG (2008) Growth and nitrogen accumulation by common bean plants originating from seeds with high molybdenum concentration. Revista Brasileira de Ciência do Solo, 32:1635-1641.

Leal MDA, Guerra JGM, Peixoto RDG \& Almeida DD (2012) Performance of crotalaria cultivated at different sowing and cutting dates. Revista Ceres, 59:386-391.

Liu L, Xiao W, Li L, Li DM, Gao DS, Zhu CY \& Fu XL (2017) Effect of exogenously applied molybdenum on its absorption and nitrate metabolism in strawberry seedlings. Plant Physiology and Biochemistry, 115:200-211.

Lopes JF, Coelho FC, Rangel OJP, Rabello WS, Amaral Gravina G \& Vieira HD (2014) Foliar fertilization with nickel and molybdenum in common bean cv. 'Ouro Vermelho'. Revista Ceres, 61:234-240.

Marur CJ, Mazzafera P \& Magalhães AC (2000) Nitrate reductase activity in cotton plants under water deficit and after turgescence recovery. Scientia Agrícola, 57:277-281.

Matoso SC \& Kusdra JF (2014) Nodulation and growth of bean in response to application of molybdenum and rhizobia inoculation. Revista Brasileira de Engenharia Agrícola e Ambiental, 18:567-573. 
Nie Z, Hu C, Liu H, Tan Q \& Sun X (2014) Differential expression of molybdenum transport and assimilation genes between two winter wheat cultivars (Triticum aestivum). Plant physiology and biochemistry, 82:27-33

Oliveira AES, Simeão M, Mousinho FEP \& Gomes RLF (2014) Desenvolvimento do feijão-fava (Phaseulus lunatus L.) sob déficit hídrico cultivado em ambiente protegido. Holos, 1:143151

Pereira VGC, Gris DJ, Marangoni T, Frigo JP, Azevedo KD \& Grzesiuck AE (2014) Agroclimatic Requirements for Common Beans (Phaseolus vulgaris L.). Revista Brasileira de Energias Renováveis, 3:32-42.

Pessoa ACS, Ribeiro AC, Chagas JM \& Cassini STA (2000) Molybdenum leaf concentration and nutrient accumulation by common beans "ouro negro" in response to leaf molybdenum application. Revista Brasileira de Ciência do Solo, 24:75-84.

Pessoa ACS, Ribeiro AC, Chagas JM \& Cassini STA (2001) Nirogenase and nitrate reductase activities and productivity of common beans in response to foliar application of molibdenum. Revista Brasileira de Ciência do Solo, 25:217-224.

Pires AA, Andrade Araújo GA, Leite UT, Zampirolli PD, Ribeiro JMO \& Meireles RC (2005) Molybdenum partitioning and foliar application time on common bean leaves mineral composition. Acta Scientiarum. Agronomy, 27:25-31.
Santos VS \& Júnior JHC (2003) Influence of the meteorological elements in the production of green manures sown in different periods. Revista Brasileira de Engenharia Agrícola e Ambiental, 7:91-98.

Silva FAS \& Azevedo CAV (2016) The Assistat Software Version 7.7 and its use in the analysis of experimental data. African Journal of Agricultural Research, 11:3733-3740.

Soil Survey Staff (2014) Keys to Soil Taxonomy. 12 ${ }^{\text {th }}$ ed. Washington, USDA. 372p.

Tedesco MJ, Gianello C, Bissani CA \& Volkweiss SJ (1995) Análise de solo, plantas e outros materiais. 174p. (Boletim Técnico de Solos, 5).

Toledo MZ, Garcia RA, Pereira MRR, Boaro CSF \& Lima GPP (2010) Nodulação e atividade da nitrato redutase em função da aplicação de molibdênio em soja. Bioscience Journal, 26:858864

Vargas TO, Diniz ER, Santos RHS, Lima CTA, Urquiaga S \& Cecon PR (2011) Influence of the biomass of legumes on cabbage yield held in two consecutive crops. Horticultura Brasileira, 29:562-568. 